\title{
Establishing the availability of the sigmodontine binomen Geoxus lafkenche (Rodentia, Supramyomorpha, Cricetidae)
}

\author{
Pablo Teta ${ }^{1 *}$ and Guillermo D’Elía ${ }^{2 *}$ \\ ${ }^{1}$ Division Mastozoología, Museo Argentino de Ciencias Naturales “Bernardino Rivadavia”, Avenida Angel Gallardo 470, C1405DJR \\ Buenos Aires, Argentina. Email:antheca@yahoo.com.ar (PT). \\ ${ }^{2}$ Instituto de Ciencias Ambientales y Evolutivas, Facultad de Ciencias, Universidad Austral de Chile, Valdivia, Chile. Email: guille. \\ delia@gmail.com (GD). \\ * Corresponding author
}

\begin{abstract}
The sigmodontine species name Geoxus lafkenche proposed by Teta and D'Elía (2016) is unavailable, given that the publication where it originally appears did not satisfy the requirements of the International Code of Zoological Nomenclature. In this note we establish the availability of the species name Geoxus lafkenche, by fulfilling those requirements.

El nombre de la especie sigmodontina Geoxus lafkenche, propuesto por Teta and D’Elía (2016), no está disponible, dado que la publicación donde el mismo fue propuesto no cumplió todos los requisitos del Código Internacional de Nomenclatura Zoológica. En esta nota establecemos la disponibilidad del nombre de la especie Geoxus lafkenche, cumpliendo esos requisitos.
\end{abstract}

Keywords: Abrotrichini; Chile; Taxonomy; Sigmodontinae.

(C) 2020 Asociación Mexicana de Mastozoología, www.mastozoologiamexicana.org

\section{Introduction}

In 2016, Teta and D'Elía published a revision of the genus Geoxus Thomas 1919, proposing a new species, Geoxus lafkenche, for the population from Guafo island, a small Pacific island in the Región de Los Lagos, Chile. The study was published in an electronic only journal. The Fourth Edition of the International Code of Zoological Nomenclature (ICZN 1999) and the Amendment on e-publication (ICZN 2012) establish that to be available, taxonomic names proposed in works that are issued and distributed electronically, must be registered in the Official Register of Zoological Nomenclature (Zoobank) prior to publication, and must include evidence of registration within the work itself. This is most often is done by providing the ZooBank Life Science Identifier (LSID) for the publication. In addition, the ZooBank registration record must include an ISSN for the journal, and an intended online archive. None of these requirements were satisfied in the publication by Teta and D'Elía (2016), where the new binomen Geoxus lafkenche was presented. As such, the name is not available. However, all the conclusions reached by Teta and D'Elía (2016) about species limits remain valid.

The objective of this note is to comply with the provisions of The International Code of Zoological Nomenclature (ICZN 1999, 2012) to make the name Geoxus lafkenche available. The information provided below was taken from Teta and D'Elía (2016). This published work and the nomenclatural act it contains have been registered in ZooBank. The LSID for this publication is: urn:Isid:zoobank. org:pub:F12E2348-309A-4DE7-A481-1A9D8A46BA77. The online version of this work will be archived and available at Zenodo.

\section{Taxonomy}

Rodentia Bowditch 1821

Muroidea Illiger 1811

Cricetidae Fischer 1817

Sigmodontinae Wagner 1843

Abrotrichini D'Elía, Pardiñas, Teta, and Patton 2007

Geoxus lafkenche n. sp.

LSID urn:Isid:zoobank.org:act:db251699-c242-4f5eabf9-1943343d5647

(Figure 1)

Holotype: UACH 7339 (original number GD 1512 collected by Héctor Pavez in January 2012), an adult female preserved as skull, body in fluid, and tissue sample in alcohol. A partial (785 bp) DNA sequence of the cytochrome-b gene gathered from this specimen was deposited in Genbank with accession number KU904314.

Type locality: Punta Weather, Isla Guafo, Región de Los Lagos, Chile ( $\left.-43^{\circ} 34.000^{\prime},-74^{\circ} 49.500^{\prime}\right)$.

Distribution: only known from the type locality.

Morphological diagnosis: A large species of the genus Geoxus (length of head and body $106 \mathrm{~mm}$, skull length $\sim 29.5 \mathrm{~mm})$, characterized by its small ears $(\sim 12 \mathrm{~mm})$, relatively long tail $(\sim 66.5 \mathrm{~mm})$, and small molar teeth; pelage somewhat coarse and uniformly dark brown, slightly paler at the venter; skull elongate and fragile, with scarcely flaring zygomata; nasals and premaxillae trumpeted; zygomatic plate inclined with a nearly convex anterior border; upper zygomatic root broad, larger than to a half of the anteropos- 


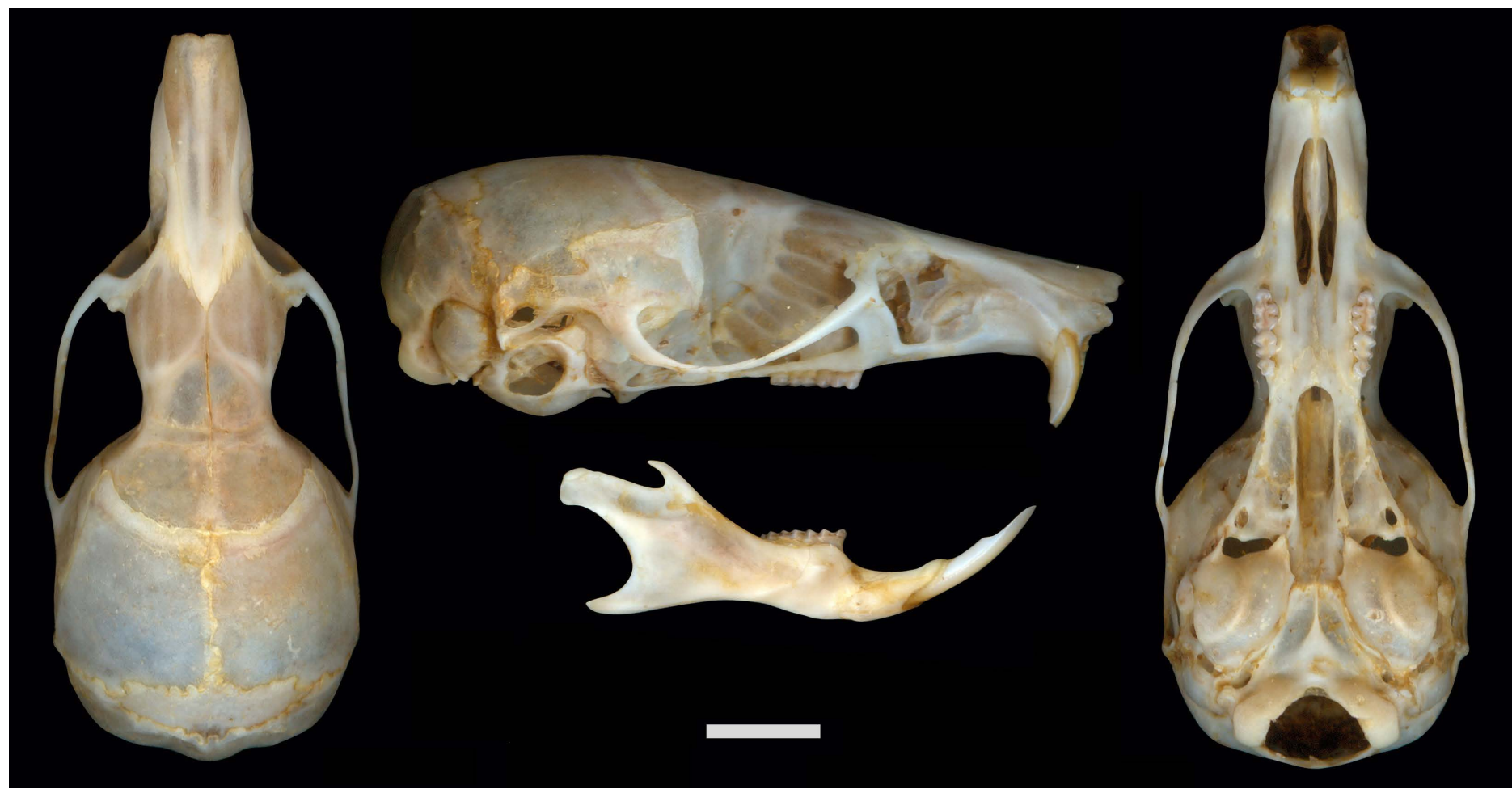

Figure 1. Holotype of Geoxus lafkenche n. sp., from Isla Guafo, Chile (UACH 7339): skull in dorsal (left), lateral (middle, above) and ventral (right) views, and left dentary (reversed) in labial view (middle, below). Scale $=5 \mathrm{~mm}$.

terior length of the zygomatic plate; frontal sinus inflated; interorbital region smoothly rounded; toothrow short; palate long, although only exceeding maxillary toothrow by the approximate length of one third of M2; parapterygoid fossa large; middle lacerate foramen broad, bridged by a sharp, well developed stapedial process; length of M3 nearly equal to three quarters of the length of $M 2$.

Etymology: From the mapudungun, the language spoken by Mapuches: lafken (= sea) and che (= people). The specific epithet corresponds to the group of the indigenous people that live along the Pacific coast of south-central Chile.

Measurements of the holotype: external measurements (in $\mathrm{mm}$, taken from specimen tag): total length (TL), 173; tail length ( $T), 67$; hindfoot length (HFL) with and without claw, 15 and 12; ear length (EL), 12.5. Cranial measurements (in $\mathrm{mm}$ ): skull length (SL), 31.38; condylo-incisive length (CIL), 28.22; zygomatic breadth (ZB), 13.09; braincase breadth (BB), 12.90; palatilar length (PalL), 11.90; incisive foramina length (IL), 5.51; incisive foramina width (IW), 1.69; diastema length ( $D L), 8.16$; maxillary toothrow length (TRL), 3.73; palatal width at M1 (PWM1), 5.12; palatal width at M3 (PWM3), 4.29; zygomatic plate width (ZW), 1.79; nasal length (NL), 11.89; nasal width (NW), 3.49; rostrum width (RW), 4.29; frontal sinus width (FSW), 6.68; interorbital breadth (IB), 5.33; frontal length (FL), 8.90; parietal length (ParL), 6.75; mesopterygoid fossa breadth (MB), 1.45.

Paratype: UACH 7340, an adult female, collected at the same locality of the holotype. A partial (793 bp) DNA sequence of the cytochrome-b gene gathered from this specimen was deposited in Genbank with accession number KU904315.
Measurements of the paratype: External measurements (in $\mathrm{mm}$ ): TL, -; T, 66; HF (with claw), 14; HF (without claw), 11; $\mathrm{E}$, 12.0. Cranial measurements (in $\mathrm{mm}$ ): $\mathrm{SL}, 28.65$; $\mathrm{CIL}, 26.01$; ZB, 12.51; BB, 12.75; PalL, 11.47; IL, 5.16; IW, 1.37; DL, 7.27; TRL, 3.80; PWM1, 5.12; PWM3, 4.68; ZW, 1.45; NL, 11.40; NW, 3.16; RW, 4.24; FSW, 6.34; IB, 5.35; FL, 9.07; ParL, 5.73; MB, 1.35 .

\section{Final remarks}

The morphological comparisons of Geoxus lafkenche n. sp. with the other species of the genus Geoxus (i. e., G. annectens, G. michaelseni, and G. valdivianus) and their phylogenetic relationships can be found in Teta and D'Elía (2016). The year of availability of G. lafkenche n. sp. is 2020 and as such must be referred in future works.

\section{Acknowledgments}

We express our gratitude to Richard L. Pyle for his valuable assistance regarding distinct aspects of the Zoobank registration.

\section{Literature cited}

International Commission on Zoological Nomenclature (ICZN). 1999. International Code of Zoological Nomenclature. Fourth edition. International Trust for Zoological Nomenclature, London, UK.

International Commission on Zoological Nomenclature (ICZN). 2012. Amendment of Articles 8, 9, 10, 21 and 78 of the International Code of Zoological Nomenclature to expand and refine methods of publication. ZooKeys 219:1-10. https://doi.org/10.3897/zookeys.219.3944. 
Teta, P., AND G. D'Elía. 2016. Taxonomic notes on the longclawed mole mice of the genus Geoxus (Cricetidae), with the description of a new species from an oceanic island of southern Chile. Hystrix, The Italian Journal of Mammalogy 27. DOI: https://doi.org/10.4404/hystrix-27.2-11996.

Associated editor: Sergio Ticul Álvarez-Castañeda

Submitted: May 17, 2020; Reviewed: May 19, 2020;

Accepted:May 19, 2020 Published on line:May 25, 2020. 
AVAILABILITY OF THE NAME GEOXUS LAFKENCHE

224 THERYA Vol. 11 (1): 221-223 